\title{
Correction to: One Year of Dapaglifozin Add-On Therapy Ameliorates Surrogate Indexes of Insulin Resistance and Adiposity in Patients with Type 2 Diabetes Mellitus
}

\author{
Stefano Radellini - Enrica Vigneri - Valentina Guarnotta • \\ Felicia Panto $\cdot$ Carla Giordano (1)
}

Published online: July 27, 2021

(C) The Author(s) 2021

\section{Correction to: Diabetes Ther (2021) 12:1677-1688 \\ https://doi.org/10.1007/s13300-021-01056-4}

In the original article, the incorrect funding note has been published. The correct funding statement is "No funding or sponsorship was received for this study or publication of this article. Editorial support was provided by Edra S.p.A, and the rapid service fee was unconditionally funded by AstraZeneca."

The original article has been updated.

Open Access. This article is licensed under a Creative Commons Attribution-NonCommercial 4.0 International License, which permits any non-commercial use, sharing, adaptation, distribution and reproduction in any medium or format, as long as you give appropriate credit to the original author(s) and the source, provide a link to the Creative Commons licence, and indicate if changes were made. The images or other third party material in this article are included in the article's Creative Commons licence, unless indicated otherwise in a credit line to the material. If material is not included in the article's Creative Commons licence and your intended use is not permitted by statutory regulation or exceeds the permitted use, you will need to obtain permission directly from the copyright holder. To view a copy of this licence, visit http:// creativecommons.org/licenses/by-nc/4.0/.

The original article can be found online at https://doi. org/10.1007/s13300-021-01056-4.

S. Radellini · E. Vigneri · V. Guarnotta $(\bowtie)$.

F. Panto - C. Giordano $(\bowtie)$

Section of Endocrinology, Department of Health

Promotion Sciences, Maternal-Infant Care, Internal

Medicine and Specialties of Excellence

"G.D'Alessandro" (PROMISE), University Hospital

P. Giaccone, University of Palermo, Piazza Delle

Cliniche 2, 90127 Palermo, Italy

e-mail: valentina.guarnotta@unipa.it

C. Giordano

e-mail: carla.giordano@unipa.it 